\title{
PROTECTED AREA DOWNSIZING; CHALLENGES AND ECOLOGICAL IMPLICATIONS ON LARGE MAMMAL AND BIODIVERSITY CONSERVATION IN CHIRISA SAFARI AREA (CSA)
}

\author{
Mahakata Innocent ${ }^{1}$ and Bishi Takwana Muindisi ${ }^{2}$ \\ ${ }^{1}$ Zimbabwe Parks and Wildlife Management Authority. Department of Terrestrial Ecology, \\ Sengwa Wildlife Research Institute, P. Bag. 6002, Gokwe, Zimbabwe. \\ E-mail: innocentmahakata@gmail.com
}

${ }^{2}$ School of Agroecology Department, Fambidzanai Permaculture Centre, Stapleford, Mt Hampden, Harare

Cite this article:

Mahakata I., Bishi T.M. (2021), Protected Area Downsizing; Challenges and Ecological Implications on Large Mammal and Biodiversity Conservation in Chirisa Safari Area (CSA). African Journal of Environment and Natural Science Research 4(4), 134149. DOI: $10.52589 / A J E N S R-$ JP7JSCDN

\section{Manuscript History \\ Received: 27 Aug 2021 \\ Accepted: 17 Sept 2021 \\ Published: 4 Dec 2021}

Copyright $\odot 2020$ The Author(s). This is an Open Access article distributed under the terms of Creative Commons AttributionNonCommercial-NoDerivatives 4.0 International (CC BY-NC-ND 4.0 ), which permits anyone to share, use, reproduce and redistribute in any medium, provided the original author and source are credited.
ABSTRACT: Protected area (PA) downsizing has been documented worldwide, but associated challenges on biodiversity and large mammal conservation in Chirisa Safari Area (CSA) are poorly understood. This study assesses the challenges associated with CSA downsizing on large mammals and biodiversity conservation. Field observations and face-to-face interviews were done with park management of CSA and SWRI from the $28^{\text {th }}$ May 2021 to $10^{\text {th }}$ June 2021. Analysis of station records on illegal activities, human-wildlife conflict (HWC) reports and land cover changes from 2010 to 2020 was also done. Poaching, encroachment by local people and veld fires, habitat fragmentation and $H W C$ were sighted as major threats to large mammal biodiversity conservation in CSA. Analysed land cover and land use changes show evidence of the expansion of cultivation land and human settlements into areas that previously served as wildlife habitats. These changes have implications on large mammal and biodiversity conservation in CSA related to species migration, population decline, habitat loss and conflicts. We recommend that further research be undertaken in other areas affected by downsizing in Zimbabwe to aid knowledge in explaining its effect on large mammals and biodiversity conservation in adjacent PAs.

KEYWORDS: Downsizing, Chirisa Safari Area, Poaching, Habitat loss, Human-wildlife conflict, Challenges, Implications. 


\section{INTRODUCTION}

Mascia et al., (2011) define protected area (PA) downsizing as decreasing the size of a PA as a result of excision of land or sea area through a legal boundary change. Downsizing results in loss of legal protection to certain areas of the PA. In 2014, the Government of Zimbabwe promulgated Statutory Instrument (S.I) 47 of 2014, for Chirisa Safari Area (CSA) to move about $250 \mathrm{~km}^{2}$ and save it for human settlement. This legal process tempered regulations, shrink CSA boundaries and eliminate legal protections originally associated with the establishment of the CSA. It resulted in conservation challenges and implications that are detrimental to biodiversity conservation. This study explores management challenges and implications on large mammal and biodiversity conservation as a result of CSA downsizing, hence contributing to the ongoing debate and available knowledge on explaining ecological implications associated with PA downsizing.

\section{Background}

In Zimbabwe, PA downsizing had attracted attention from PA management, ecologists and policymakers. Although PA downsizing is associated with conservation planning, in Zimbabwe, most were meant to accommodate human settlement, agriculture and mining, a point in case being Save Valley Conservancy, Hwange National Park and CSA. A research study on PA downsizing reported significant tradeoffs between conservation priorities and other policy objectives (Mascia et al., 2014). One of the key objectives of the Convention on Biological Diversity (CBD) strategic plan is to increase PA coverage through promoting the creation of wildlife corridors and encouraging sustainable utilisation of wildlife resources by communities adjacent to PAs (Zimbabwe Biodiversity and Tropical Forest Assessment (118/119), 2012). In contrast, approximately $250 \mathrm{~km}^{2}$ was removed from CSA contributing to almost twelve per cent of the CSA.

PAs are considered to play an important role in conserving biological diversity (Wells \& Brandon 1993). PAs are among the most effective conservation measures, critical to global efforts in safeguarding species and mitigate the impacts of climate change (Chape et al., 2005; Melino et al., 2016). Today, PAs aim to conserve biodiversity in large scale natural ecosystems. However, PAs are increasingly facing several challenges (Wearing and Neil, 1999; Suich, 2008). The tendency of establishing human settlements in previously wildlife areas is becoming common and endangering the future life of wildlife species (Ogutu et al., 2012). PAs downsizing for human settlement compromise biodiversity conservation efforts and ecosystem services afforded by PAs (Golden Kroner, Rachel et al., (2019). Such is the case with CSA, where the large mammal conservation is under threat due to challenges ranging from humanwildlife conflicts (HWCs), veld fires and poaching (Gratwicke and Stapelkamp, 2006).

Focussing on CSA, this study examines current challenges and implications associated with CSA downsizing for large mammal and biodiversity conservation in CSA. To achieve this, the two specific objectives raised were; (a) To access current problems associated with the conservation of large mammals and biodiversity in the exercised area of CSA, and (b) To predict future implications on conservation of large mammals and biodiversity in CSA. 


\section{METHODOLOGY}

\section{Study Area}

CSA is a statutory PA that was established in 1965 in North West Zimbabwe. CSA is located about $18^{0} 10^{\prime} \mathrm{S}$ and $28^{\prime} 014 \mathrm{E}$. It was reduced to approximately $1400 \mathrm{~km}^{2}$ following the promulgation of SI 47 of 2014 which claimed about $250 \mathrm{~km}^{2}$ to accommodate human settlement in the south-eastern side of the area (Figure, 1). Rainfall is characterised by monthly and intraannual variability with a mean annual rainfall of $600 \mathrm{~mm}$. Average maximum temperatures are $28^{\circ} \mathrm{C}$ towards the rainy season, whereas mean minimum temperatures are above $13^{\circ} \mathrm{C}$. Three seasons are experienced: the hot wet (November-April), the cool dry (May-July) and the hot dry (August-October) (Tafangenyasha et al., 2016). The area is typical of a semi-arid environment. Dominant vegetation types are: Colophospemum mopane species in the central part, Acacia dominated bushland occur along major rivers (Manyoni, Sengwa, Mugurazino and Gadzi) Miombo woodlands dominate the periphery of the CSA. The rest lower areas are occupied by mixed Baikiaea-Combretum dominated woodlands and grasslands along with riverine areas of Manyoni, Gadzi and Matsakinya.

The main activities undertaken in the excised area are farming and livestock keeping. Extractive use of park resources includes timber, firewood, medicinal plants, honey, and hunting for bushmeat. CSA hosts a variety of mammalian, avian, and reptilian species. The CSA has at least 100 vascular plant species, of which 21 are endemic, 230 bird species, 18 mammal species, 15 reptile species, 50 amphibian species, and 5 fish species.

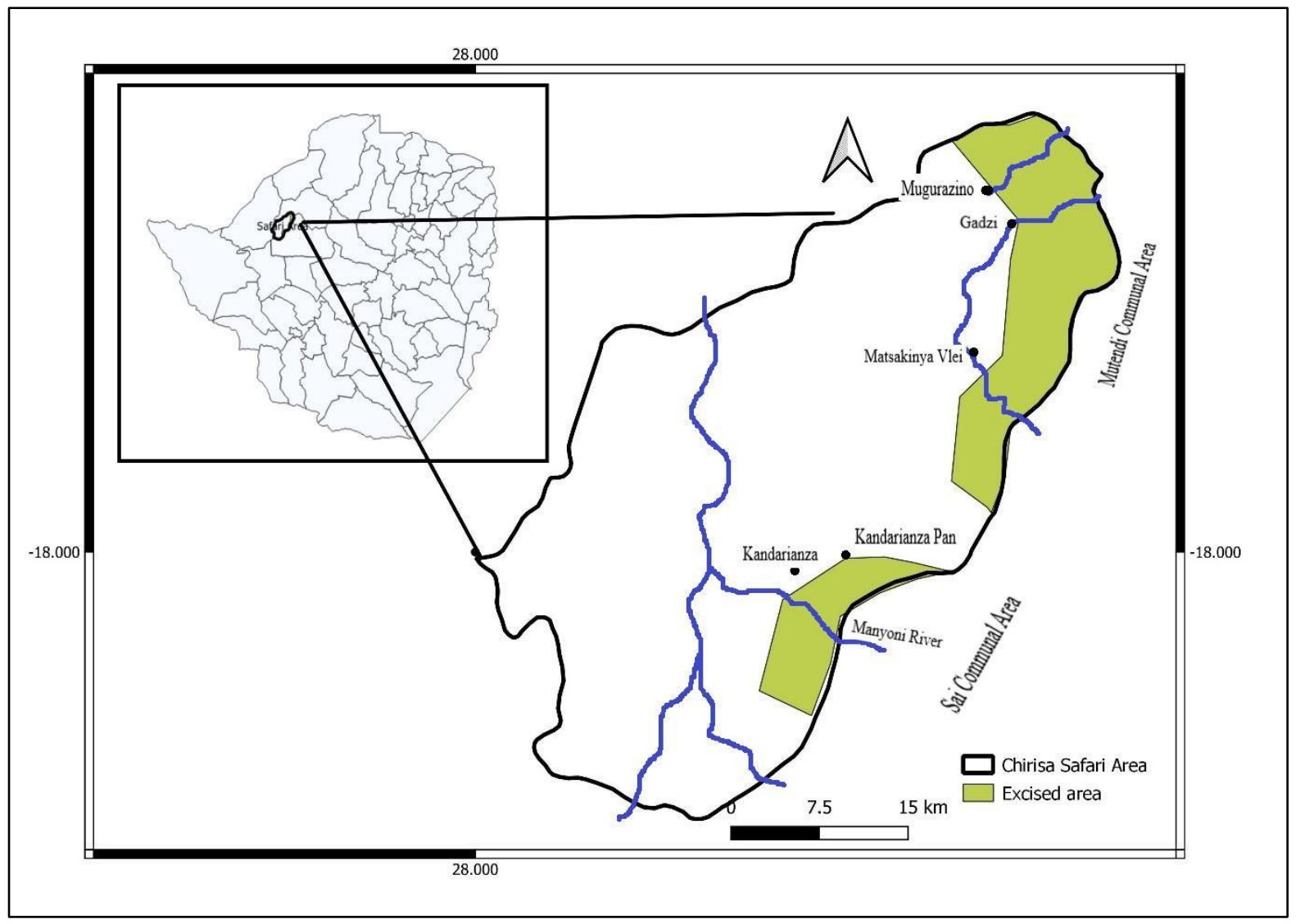

Figure 1: Map showing the location of the excised area of CSA. 


\section{Data Collection}

Information on current challenges being faced as a result of downsizing CSA following enactment of S.I. 47 of 2014 was found through site visits and from CSA and Sengwa Wildlife Research Institute (SWRI) offices. Two methods were used in data collection; (a) Site visit for direct observation and face to face interviews with CSA park managers was done from the $28^{\text {th }}$ May 2021 to $10^{\text {th }}$ June 2021. The site visit was also complemented by secondary data obtained from station records on land-use changes, animal sightings, poaching, veld fires incidence and HWC. During the visit, open-ended interview discussions were done with the aim to obtain details on biodiversity conservation challenges emanating from human settlement, livestock grazing, agricultural expansion among others. Eight people were interviewed. The researcher observed the environmental parameters affected by human activities in the study area. Data on nature and environmental parameters including vegetation status, wild animal movements, soils status, state of rivers and water sources were recorded. Processed map obtained from the SWRI on land cover dynamics from 2010 to 2020 was analysed to identify land cover changes associated with human activities.

Face to face interviews with CSA Park management focused on establishing changes before and after settlement in species sighting, the incidence of poaching, the existence of key species in and outside settled areas, the incidence of people visiting from other areas for different activities in the newly settled areas, challenges faced in the conservation of biodiversity and large mammals species, conservation enforcement and whether settlers comply with adjacent CSA rules to protect biodiversity and conservation of large mammal?

\section{Data Analysis and Interpretation}

Quantitative data on veld fire incidence, HWCs and poaching incidence were analysed using graphical methods in MINITAB software. All other qualitative data from researcher observations, descriptive methods were used to construe observations. Changes in landcover from 2010 to 2021 were interpreted from a processed landcover map of CSA to determine changes over time.

\section{RESULTS}

Conservation challenges identified were related to the increase in poaching of key species, related encroachment into CSA by settlers and veld fires (Figure 1), habitat fragmentation associated with land cover changes due to land clearing as well as habitat loss associated with contamination and siltation of water sources in Matsakinya and Manyoni area. An increase in HWC by almost 30 per cent (Figure 2) per annum after human settlement as a result of competition for grazing areas between livestock and wild animals and between community and park (Figure 3).

\section{Poaching of Key Species}

Between 2015 and 2020, six elephant carcasses were recorded in the excised area of CSA compared to four recorded between 2010 and 2014. Death related to poaching in buffaloes increased from an average of one per annum between 2010 and 2014 to an average of seven from 2015 to 2018. However, a decrease to an average of four was recorded between 2019 and 
2020. Eland, waterbucks, zebras and kudu showed no changes in the number of poached animals from records with an average of four recorded death linked to poaching incidence (Table 1). Poaching activities were linked to poisoning, snaring and use of dogs.

Table 1: Number of animals poached for each species before and after settlement in the excised area of CSA.

\begin{tabular}{|l|c|c|}
\hline \multirow{3}{*}{ Species } & \multicolumn{2}{|c|}{ Period } \\
\cline { 2 - 3 } Elephants & $2010-2014$ & $2015-2020$ \\
\cline { 2 - 3 } Buffalo & 4 & 7 \\
Waterbuck & 1 & 5 \\
Zebra & 4 & 4 \\
Kudu & 4 & 4 \\
\hline
\end{tabular}

Incidence of poaching for waterbuck, zebra and kudu were difficult to detect because in most cases, illegal hunters took everything from the carcasses killed.

\section{Human and veldfire encroachment into CSA.}

Veldfire encroachment from adjacent settled areas increased from 2014 to 2016, and a decrease was recorded from 2017 to 2019, (Figure 1).

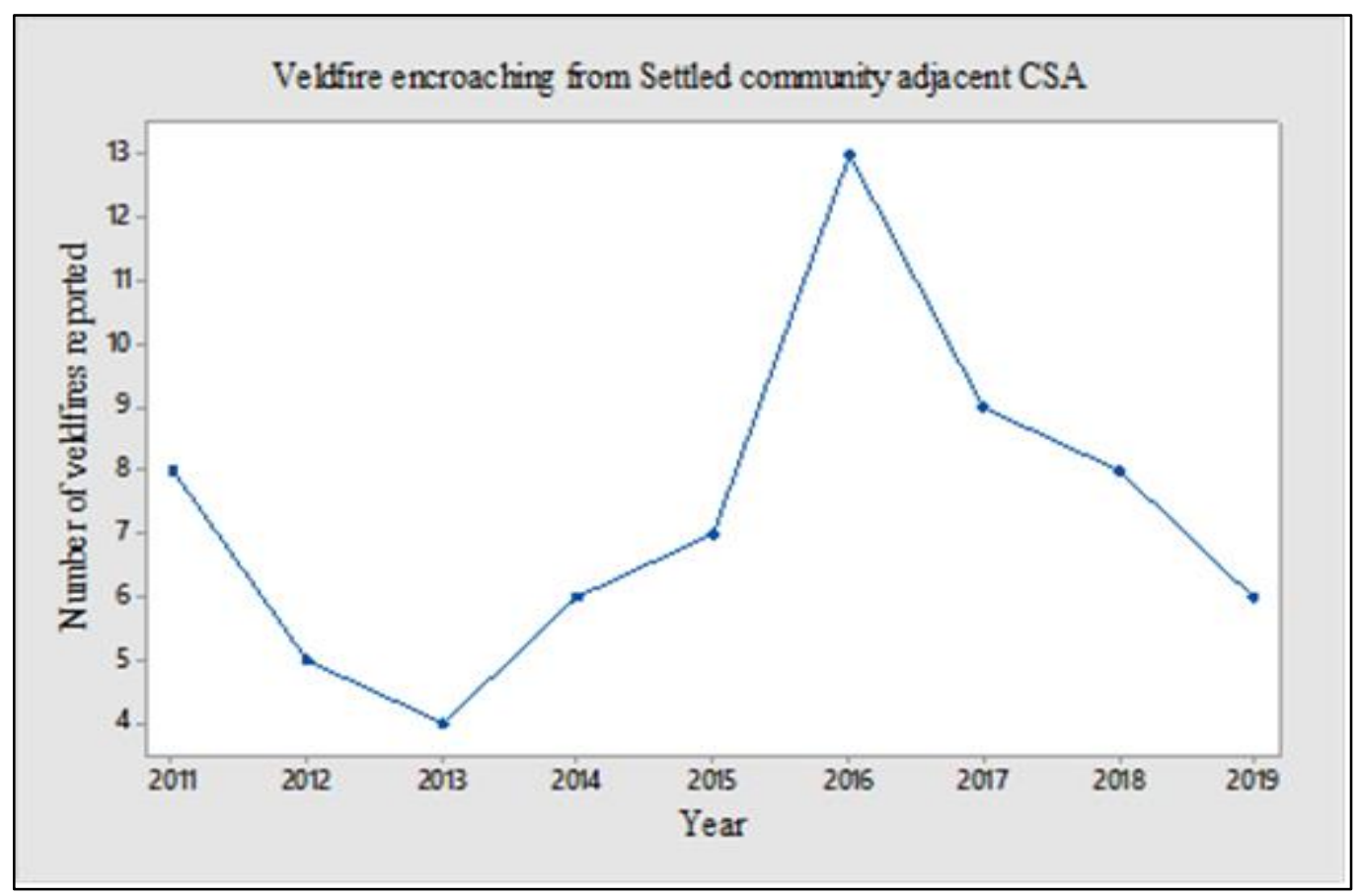

Figure 1: Change in the number of veld fires encroaching into CSA before and after human settlement. 
Incidences of illegal human activities were also recorded (Figure 2) and GPS coordinates where the incidence of encroachments by people was recorded from different activities. Cattle sightings were recorded in water points that is Matsakinya spring, Gadzi and Mugurazino.

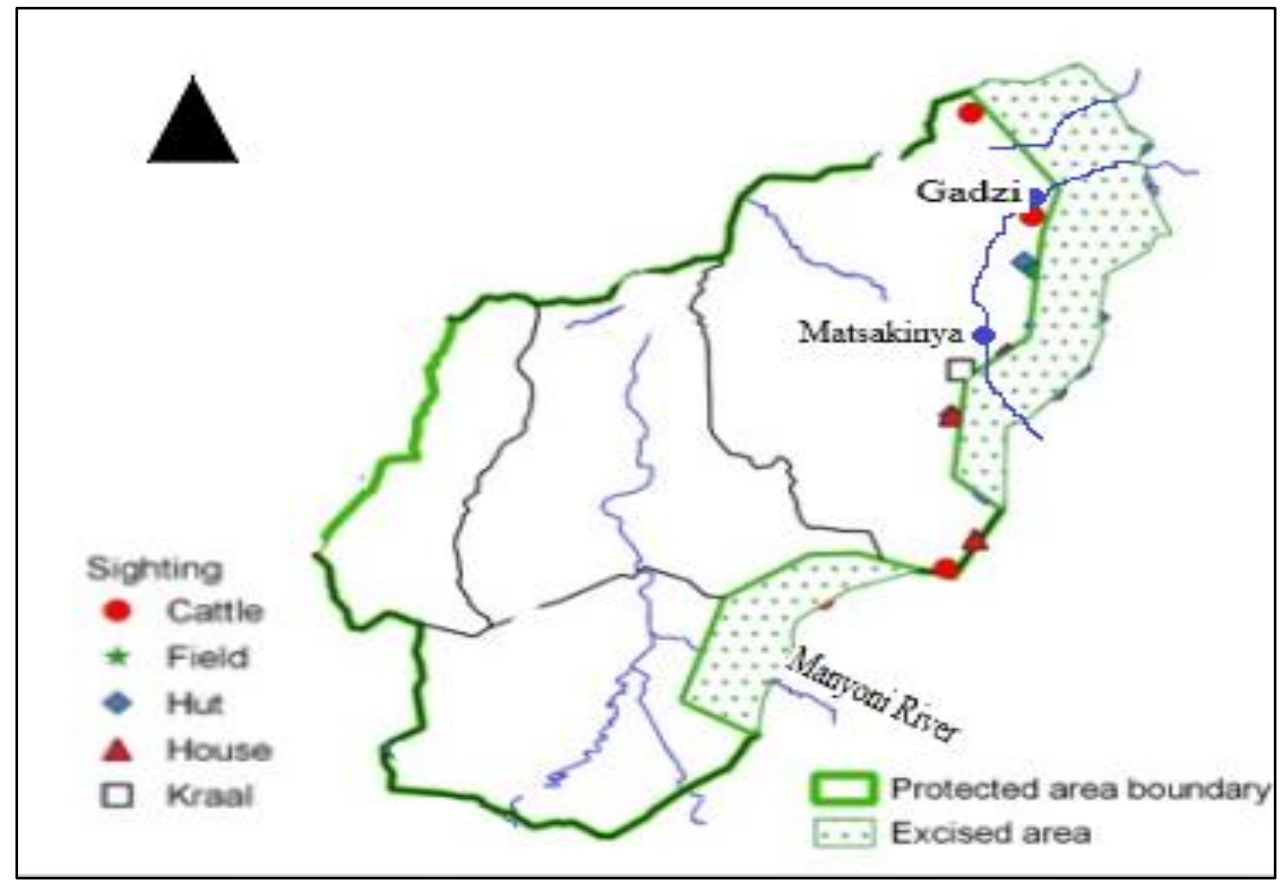

Figure 2: Map showing signs of encroachment into the CSA detected during site visit.

\section{Human-wildlife and park community conflicts}

On average, a total of forty-five reports were received per annum between 2017 and 2020 from these settled areas, a figure which tripled prior to the human settlement between 2010 and 2016. The incidence of HWC reports received at CSA from settled areas is shown in Figure 3 below. Most problem animals were elephants and hyenas which were reported to raid fields and killing livestock respectively. The graph shows an increase in the number of reports received from 2016 to 2019 inclusive of different species involved. 


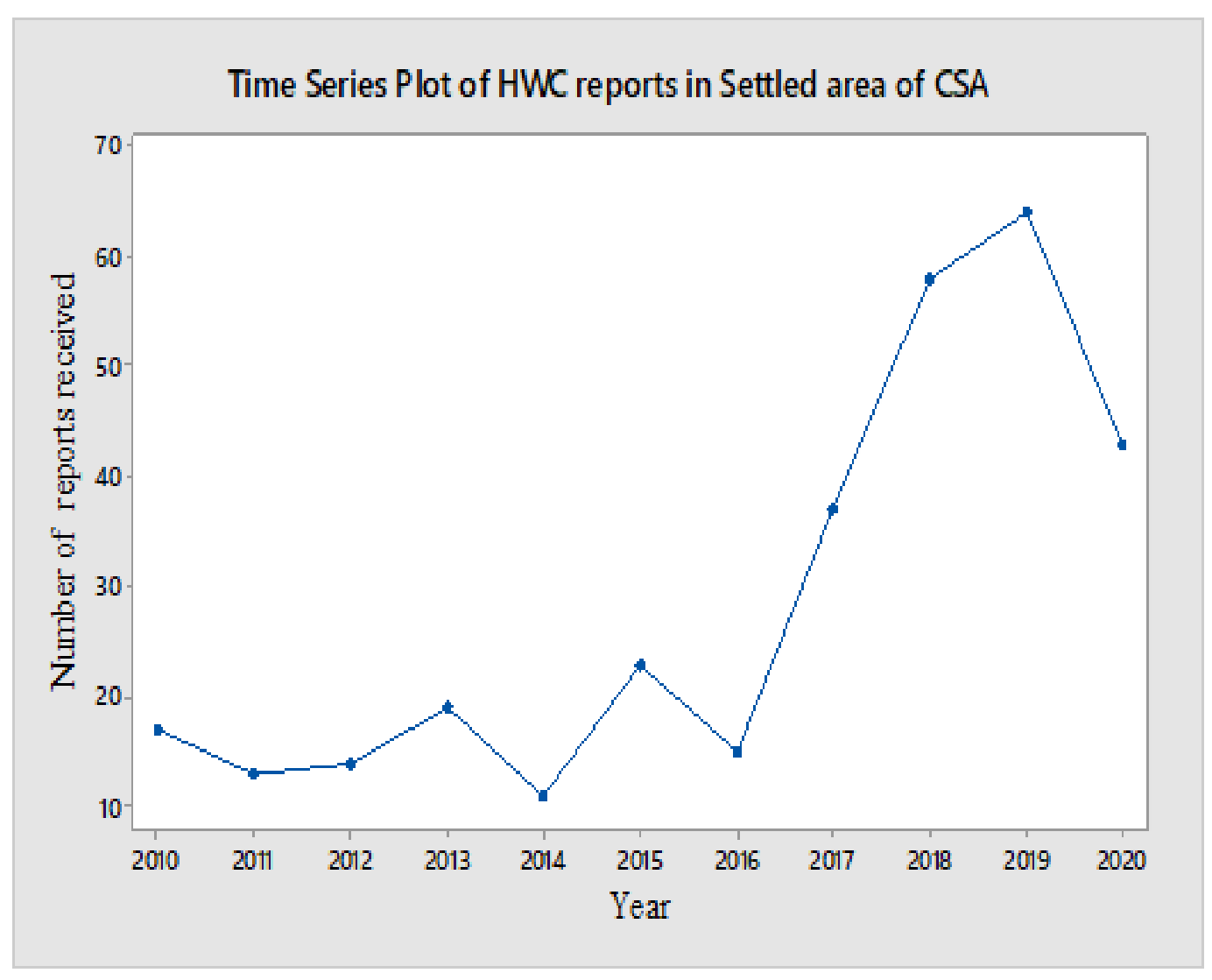

Figure 3: Graph showing annual trends in HWC reports received from 2010 to 2012 in settled areas of CSA.

\section{Habitat fragmentation and loss}

The settled area experienced extensive vegetation clearing showing some light stratum cleared over time. Vegetation cover changes in the settled areas showed light stratum cleared and possible encroached hotspots associated with human influence in CSA over time from 2010 to 2020 (Figure 4). Other parts with less human influence, showed stratum with persistent light to dense landcover. 


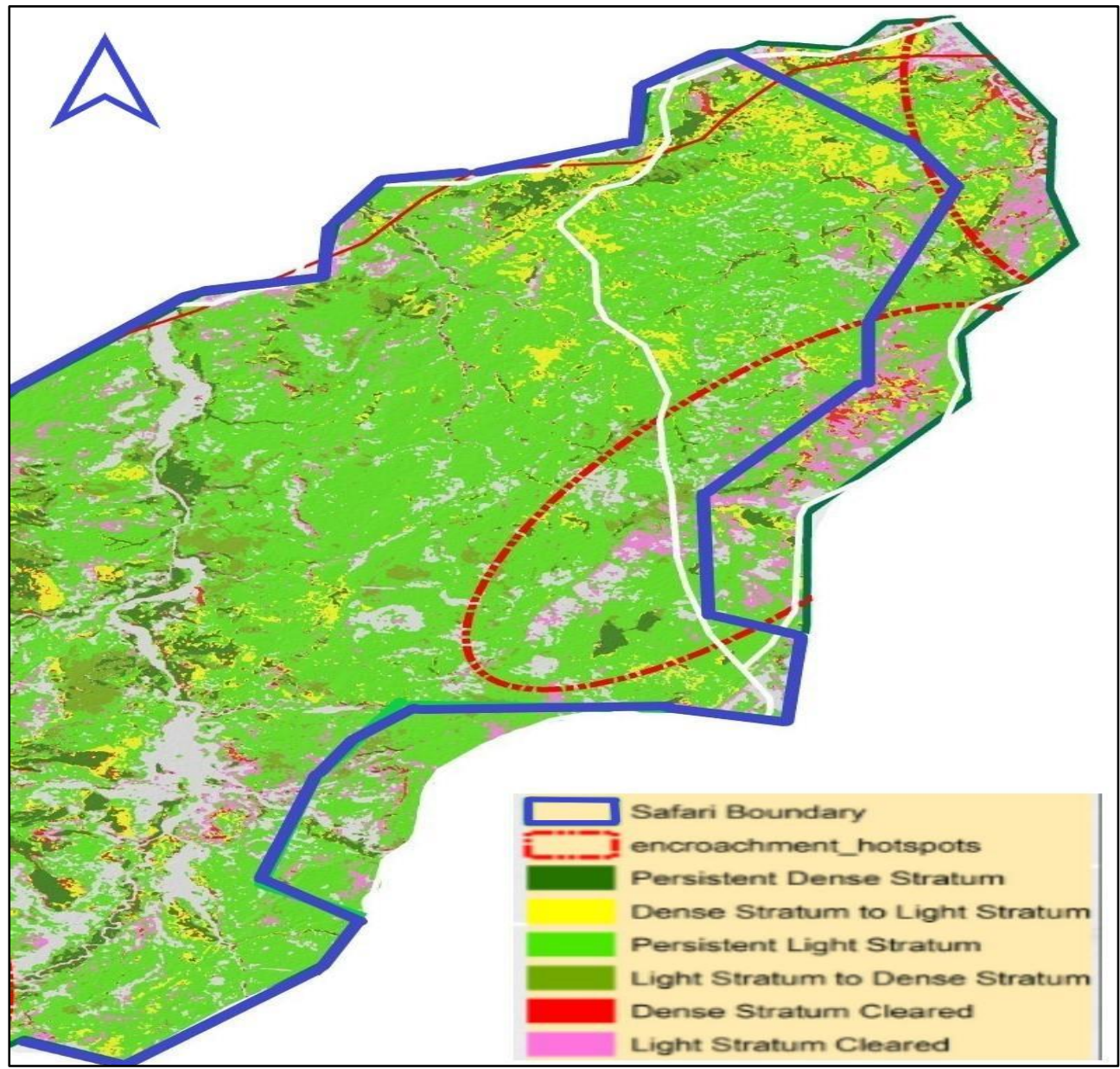

Figure 4: Map showing land cover dynamics between 2010 and 2020 in CSA (Source: SWRI, 2020).

\section{DISCUSSIONS}

\section{Challenges associated with CSA downsizing for large mammal and biodiversity conservation}

PA downsizing in CSA is associated with several challenges including poaching of key wildlife species, encroachment into the park, escalating veld fire incidences, HWCs and fragmentation of the habitat of wildlife species among others.

\section{Poaching of key species and other wildlife resources in CSA.}

Manyoni $\left(80 \mathrm{~km}^{2}\right)$ which is part of the exercised area, has not been settled and represents a major threat to wildlife conservation in CSA. Poaching of wild animals almost doubled for elephants and buffaloes while elands, zebra, waterbuck and kudu remained constant although the sightings of such species continue declining. The area had been abandoned since 2014 and no patrols to protect wildlife in the area had been taking place constantly. 
One of the challenges faced by large mammal and biodiversity conservation is poaching (Giangaspero and Ghafri, 2014). Poaching activities in Africa have increased in the past few years due to demand for certain skins, ivory, bones and other products for cultural, medicinal and socio-economic reasons (Ntuli et al., 2021). This includes preferably elephants and other large mammals whose products are on demand and have encouraged a lot of poaching (Obour et al., 2016). Wildlife is no longer regarded as a resource but a liability by the settled area which has a negative impact on their livelihood (Mainka and Trivedi, 2002), hence community view wildlife as something without value that had to be destroyed or poached and this poses a challenge in large mammals and biodiversity conservation in CSA.

\section{Human activities encroachment and veld fires}

The peripheries of CSA sharing boundaries with the settled area of Mutendi and Manyoni reported the highest fire incidence from 2014 to 2020 than any other area probably because it shares boundaries with highly populated communal areas (Mpakairi et al., 2018). In the Manyoni area, an average of one veldfire per annum encroaching into the CSA has been recorded, a record higher compared to an average of one veldfire per every two to three years reported from 2001 to 2013. The other part of the resettled area recorded double numbers from an average of three veld fires to six veld fires per annum encroaching into the PA

The findings support earlier observations that increased human settlement around PAs in the Sebungwe Region after tsetse eradication in the late 1970s increased the occurrence of wildfires in protected areas (Mapaure and Campbell, 2002). Although it is difficult to ascertain the actual cause of fire outbreaks, there is no doubt that human activities could be the main source (Bistinas et al., 2014). Hence, the interaction of anthropogenic factors may lead to an increase in the number of wildfires encroaching from the settled communal areas according to Nyamadzawo et al., (2013). Associated with poaching activities are bush fires that cause much destruction of plant and animal species (Muboko et al., 2014).

The uncleared boundary that demarcates communal areas and PA may also facilitate veld fires crossing into PAs (Dube, 2013). Where settlers burnt the forest to clear fields and ending up failing to put off the fires due to high moribund materials accumulated for long result in veld fires encroaching into PAs (Nyamadzawo et al., 2013).

\section{Human-wildlife and park community conflicts.}

Settlement claimed part of the wildlife habitats around CSA contributing to increased conflict between wildlife and people. CSA is becoming increasingly isolated due to settlement and this brought immense challenges to park management. Conflicts related to poaching of wildlife resources, wood extraction and illegal livestock grazing occur. In addition, isolated wild animals threaten the livelihood of communities according to Jones and Barnes (2006). Despite a drastic decline in elephant population in Sebungwe Elephant Range Area between 2006 and 2014 (Dunham et al., 2015) however, there has been intense HWCs around CSA. Human elephant conflicts had been fueled because elephants traditionally used to utilize these areas, in some cases as migratory routes. HWCs reactions are now based on the use of lethal methods which threaten wildlife conservation, as the community has limited alternative livelihoods apart from subsistence farming.

In most African countries, conflicts over natural resources are frequent (Stewart, 2002). The increased human pressure in CSA has contributed immensely to limited space for large 
mammal species movements such as elephants, buffaloes and big cats. The findings of the study are similar to those by Ndibalema (2010) in the Serengeti ecosystem, where shrinkage of the buffer zone area of the park and its impact on animal movements were reported. This is particularly the case in CSA, where settlement has become a threat as a result of people encroaching into wildlife areas.

Human settlements inside the CSA could have been fuelled by unclear park boundaries following the downsizing of the CSA. Settlers moved into the PA covering areas as far as three kilometres from the initial boundary gazetted in S.I 47 of 2014. This resulted in excessive loss of wildlife habitats. Even though the settlers were later moved out, animal habitats had already been affected with some fragmentations caused. Elsewhere, an investigation on challenges of human settlement on wildlife was carried out in 2014/2015 in and around Bale Mountains National Park by Hansilo and Tiki (2015). Results showed that a constant increase in human settlement from time to time leads to excessive losses of natural habitats for wild animals.

The nucleated homesteads in the form of villages were observed on the edges of Matsakinya with farmers encroaching for grazing lands and water sources. Matsakinya remained one of the water sources for wild animals. However, due to human disturbance, the animal movement had been reduced. The dimensions of the need for more space by settlers remain the major threat to biodiversity (Murray and Williamson, 2002). Some settlers occupy the buffer zone, while others remain at the boundary ending up utilising park resources illegally giving challenges in the conservation of biodiversity and large mammal species to CSA.

\section{Habitat loss and fragmentation}

Along Manyoni and Matsakinya vlei, savanna grassland is the major type of terrestrial ecosystem that supports diverse communities of herbivores. This grassland ecosystem is related to low rainfall which falls in one short summer season. In Manyoni, Gadzi and Matsakinya areas, biodiversity loss is closely linked to human settlement nearby and their activities such as clearing forests for agriculture as highlighted by Murray and Williamson (2002). An increase in human settlement in an area means an increase in demand for food and other basic needs (FAO, 2017). This usually translates into greater demand for natural resources such as land, forests and animal products from the CSA.

Peasants settled in sections of former wildlife areas use resources in a manner that usually conflicts with state land use plans according to Wallace et al., (2003) and thus, pose a challenge in large mammal conservation in CSA. The community believes they have open access to wildlife resources while the state believes access to wildlife should be strictly controlled according to Mutepfa et al., (1998). Habitat loss as a result of fragmentation can occur as reported by Kroner et al., (2016) in Yosemite National Park. PA downsizing may exacerbate habitat fragmentation, which is a key contributor to biodiversity loss globally (Kroner et al., 2016). Similar cases had been observed in the Manyoni and Gadzi sections where roads had been developed in the excised area along the periphery of CSA. This has an impact on large mammal species movement and ecosystem integrity as a result of habitat fragmentation (Rus et al., 2006).

Matsakinya spring was affected by siltation as a result of high cattle movement, overgrazing and continuous burning by settled farmers. Erosion of topsoil as a result of loose ground is deposited in Matsakinya vlei and spring. This has an impact on large mammal species such as 
buffaloes, impalas, zebras, kudu and elands. These species are no longer seen in these settled areas and nearby except for a few heads of migrating elephants which normally visit the area during the nights.

Increased conversions of rangeland habitats have negative impacts on large mammal species as their habitats are lost according to Krausman et al., (2009). The new types of land use, such as agriculture, which have occupied large space led to destructions of natural vegetation and reduced size of habitat for wild animals. Kideghesho et al., (2006) also mentioned similar problems on wildlife habitats due to cultivation in some parts of Africa with detrimental effects. In CSA, similar cases had been observed where farmers from as far as Chitekete and other places come to occupy the area with big heads of cattle hence competing with large mammals for space along the boundary and at one time, livestock kraals had been seen inside the CSA in May 2021.

\section{Implications on large mammal conservation and biodiversity of CSA}

PAs are regarded as permanent fixtures meant to protect biodiversity hence essential for the conservation of large mammals and biodiversity according to Symes et al., (2015) However, policies that tamper around with PAs have implications on large mammals, biodiversity and conservation according to Mascia, (2011). Our findings underscore significant implications on large mammal and biodiversity conservation in CSA and these include declining populations, species migration, conflicts and habitat losses.

\section{Declining populations and Species extirpation}

In both Manyoni and Matsakinya, the incidence of water poisoning had been reported in 2015, 2019 and 2020 targeting plains game, birds and large mammals such as elephants for meat and ivory. Poisoning kills wild animals in large numbers leading to a decline in species population. According to Caro et al., (2014) exploitation of wildlife occurs both outside and inside PAs and is a major driver of species declines. This is accelerated when the community live very close to PAs. According to Wilkie et al., (2011), large mammal species are more vulnerable because of their wide-ranging behaviour and are specifically targeted by hunters for meat and ivory when they move out of PAs.

Illegal harvesting has effects on sustainability and impacts of PAs on the conservation of large mammals in adjacent areas (Kroner, et al., 2016). In the Matsakinya area, the population of buffaloes and other plain game sightings are now rarely recorded. This is could have been influenced by illegal human activities such as poaching, siltation and competition for grazing lands and water with livestock. Elsewhere, evidence shows that the boundaries of PAs and their level of protection regularly change due to human activities (Tesfaw, 2018). Some species in the CSA ecosystem for example sables had gone locally extinct and this may be a result of habitat destruction and overexploitation of resources (Shemweta and Kideghesho, 2000).

According to Gaston et al., (2008), PAs remain the cornerstone intervention for protecting biodiversity including maintaining habitat integrity. Where human activities alter habitats local extirpation of wild animals can occur. According to Tesfaw et al., (2018), if a PA has maintained the integrity of its forests, then downsizing to accommodate settlements could have considerable impacts on ecosystem integrity which negatively impact large mammal survival, hence, Bogoni et al., (2020) concluded that large mammal defaunation and depletion can be accelerated primarily by poaching and declining habitat size. 


\section{Migration}

Factors that affect large mammal's distribution at a fine scale are well known and primary drivers are associated with food and water availability (Chamaillé and Fritz, 2007), with the presence of humans as an additional factor (Mpakairi et al., 2019). Habitat loss due to human settlement may disrupt species societies (Mpakairi et al., 2019). Social and behavioural disruptions as a result of anthropogenic-induced fragmentation can limit the adaptive value of animal social relationships (Backman, 2011) or alter the structure of genetic variation in animal populations leading to large mammal migration and or mortalities which affect the local population of large mammals (Foley, 2002).

Dudley (1999), reported that, for example, elephant dynamics within the semi-arid woodland landscapes are modulated by human influences on elephant population density and distributions. The findings support the same ideas by Mpakairi et al (2019), who observed that human settlements drive elephant movements in the Sebungwe region in their study carried out in the Kavango-Zambezi Transfrontier Area (KAZA). According to Parker and Graham (1989), large mammal distribution is the inverse of human distribution and that species abundance is influenced by human density at a given scale. This was supported by Mpakairi et al., (2019), who observed that human settlement drives the potential distribution of elephants in the Sebungwe Region. According to Tjove (2010), large mammal species require large undisturbed areas for survival, hence, Symes et al (2015) highlighted the need to maintain a good size of undisturbed habitats for such species.

\section{Community-Park conflicts}

Voeten and Prins (1999) indicated that livestock encroachment into PAs has implications on large mammal conservation as a result of competition for water, grazing areas and sparse for survival. Such is the case for CSA where cattle encroachment is reported in Manyoni, Gadzi and Matsakinya area. Numerous studies documented a negative relationship between livestock density and wildlife density. Large mammals and livestock compete for food where forage and water are scarce (Odadi et al., 2011). Where this occurs, direct persecution and killing of large mammals can occur by farmers protecting their livestock from competing for grazing areas.

Alteration of hydrologic processes as a result of competition for water between livestock and wild animals as well increased mortality of animal species have profound impacts on ecosystem services (Konar et al., 2013). Massive die-offs due to water shortages are likely to be observed as they have been documented elsewhere, for example, mammals in South Africa's Kalahari Gemsbok NP (Knight, 1995).

\section{Habitat loss}

Expansion of human settlements reduces the natural ranges of many wild animals (Murray and Williamson (2002). Loss of habitat due to fragmentation is one factor that can lead to species extinctions (Goldman, 2009). Van Oort, McLellan and Serroura (2011), pointed out that where humans have fragmented once contiguous habitats, wildlife will establish a new metapopulation, hence giving park managers challenges to conserve such separate areas. Kroner et al (2016) concluded that lands that are removed from PA through downsizing are highly fragmented and it restricts large mammal species dispersal. 
High human settlement in PA pose challenges to the survival and conservation of wildlife (Vial et al., 2011). Thus, according to Tesfaw et al., (2018) PA downsizing shapes rates and patterns of tropical deforestation and habitat loss as a result of fragmentation. Beckmann, (2011) pointed out that disentangling between social/behaviour-caused and habitat fragmentationcaused lack of dispersal has huge implications on how best to tackle challenges associated with habitat fragmentation for large mammal conservation. In CSA, this had been accelerated by the haphazard settling of communities leaving areas of undisturbed habitats between houses. As a result, the connectivity of spatial habitat is disrupted, a point highlighted by Caro et al., (2014), that degradation of habitat around PAs results in loss of connectivity between PAs, whereas fragmentation of PAs reduces their effective size.

Veldfire have long term implication on large mammal species and biodiversity conservation in Zimbabwe (Dube, 2015). Veldfires cause ecological disturbances that shape ecosystem structure as highlighted by Caro et al., (2014). Veldfire alters habitat structure and pose challenges to environmental management of large mammal species through habitat damage and causing death to wild animals (Everson et al., 1989). For example, severe fires in PAs in the U.S. Northwest were observed to be a risk for endangered species (Spies et al., 2006), hence regarded to have implications on the conservation of large mammals and biodiversity conservation in CSA.

The study is close to the observation of uncontrolled levels of poaching, habitat loss, encroachment of veld fires and human activities as well as park-community conflicts as a major threat to biodiversity and large mammal conservation in CSA. Soil erosion, siltation, land degradation and gullies are the main environmental effects associated with settlement and have far-reaching effects on the adjacent CSA. Awareness and educative programmes can play a key role in releasing the challenges associated with the conservation of biodiversity and large mammal conservation in CSA to maintain habitat integrity for large mammal species.

\section{Implications for Research and Practice}

This research contributes to the scientific knowledge and academic literature on explaining the impacts of PA downsizing and management in terms of challenges and its ecological implication associated with biodiversity and large mammal conservation. The study highlights the need for the study to document patterns, causes and impacts in areas affected by downsizing in Zimbabwe.

\section{CONCLUSION}

In conclusion, large mammal species and biodiversity conservation is accompanied by inter alia excessive poaching, habitat loss, encroachment and HWCs. These have so far reached implications like species migration, population decline, habitat loss and conflicts between the park and adjacent communities. Urgent measures are recommended to reduce challenges faced in the conservation of large mammals in CSA.

\section{Future Research}

Drawing on the gaps highlighted by this study, several priorities areas had been identified for future studies which should focus on habitat change monitoring as a result of human settlement 
in previous wildlife range areas, an area poorly documented in Zimbabwe. Research also has to be undertaken in other areas where downsizing had been affected in Zimbabwe, to establish the full extent of the biodiversity losses and implications associated with downsizing.

\section{Acknowledgement}

This work was made possible through support rendered by CSA Park management and SWRI during data collection and provisioning of data used in this study from station records. SWRI assisted with land cover maps used in analyzing land cover dynamics in CSA from 2010 to 2020.

\section{REFERENCE}

[1]. Tesfaw, A.T. Pfaff, A. Rachel E. Kronera, G. Qina, S. Medeiros, R. Mascia, M.B (2018). Land-use and land-cover change shape the sustainability and impacts of protected areas. www.pnas.org/cgi/doi/10.1073/pnas.1716462115

[2]. Beckmann, J.P. (2011). Understanding the role of behavioural mechanisms and impacts of habitat fragmentation on structuring small declining populations. Animal Conservation 14, 229-230.

[3]. Conservation International (2017). Prepared in Response to CBD Notification Ref.: SCBD/SPS/DC/SBG/ESE/86683: Submission of information and experiences on various elements of protected areas.

[4]. Dube, E. (2015). Environmental challenges posed by veld fires in fragile regions: The case of the Bulilima and Mangwe districts in southern Zimbabwe', Jàmbá: Journal of Disaster Risk Studies 7(1).

[5]. Dube, O.P. (2013). Challenges of wildland fire management in Botswana: Towards a community of inclusive fire management approach. Weather and Climate Extremes 1, 26-41.

[6]. Dunham, K.M. Mackie, C.S. Nyaguse, G. Zhuwau, C. (2015). Aerial Survey of Elephants and other Large Herbivores in the Sebungwe (Zimbabwe): 2014. Great Elephant Census. A Paul G. Allen Project. Zimbabwe Parks and Wildlife Management Authority.

[7]. Everson, C.S. George, W.J. Schulze, R.E. (1989). Fire regime effects on canopy cover and sediment yield in the montane grasslands of Natal', South African Journal of Science 85, 113-116.

[8]. FAO. (2017). The future of food and agriculture - trends and challenges. Rome.

[9]. FAO. (2006). Livestock impacts on the environment. Agriculture and Consumer Protection Department of the United Nations.

[10]. Gaston, K.J. Jackson, S. F. Cantu-Salazar L. Cruz-Pin on, G. (2008). The ecological performance of protected areas. Annual Review of Ecology, Evolution, and Systematics, 39, 93-113.

[11]. Giangaspero, M. Ghafri, M.A.I. (2014). Poaching: A Threat for Vulnerable Wild Animal Species in Oman. Tropical Medicine and Surgery. 02(04).

[12]. Kroner, G. Krithivasan, R.E.R. Mascia, M.B. (2016). Effects of protected area downsizing on habitat fragmentation in Yosemite National Park (USA), 1864 - 2014. Ecology and Society 21(3):22. 
[13]. Kroner, G. Krithivasan, R.E.R. Mascia, M.B. (2019). The uncertain future of protected lands and waters. (https://doi.org/10.1126\%2Fscience.aau5525).

[14]. Gratwicke, B. Stapelkamp, B. (2006). Wildlife Conservation and Environmental Management in an "Outpost of Tyranny". Zimbabwe Conservation Opinion Special Report, 3:1-39.

[15]. Jones, B.T.B. Barnes, J.I. (2006). Human-Wildlife Conflict Study: Namibian Case Study. Economic analysis. Workshop proceedings.

[16]. Bogoni, J.A. Peres, C.A. Katia, M. Ferraz, M.B. (2020). Extent, intensity and drivers of mammal defaunation: a continental-scale analysis across the Neotropics. Scientific Reports, Nature Research.

[17]. Knight, A. T. Rodrigues, A.S. Strange, N. (2013). Designing effective solutions to conservation planning problems. West Sussex, UK: John Wiley and Sons.

[18]. Konar, M. Todd, J. M. Muneepeerakul, R. (2013). Hydrology as a driver of biodiversity: Controls on carrying capacity, niche formation, and dispersal. Advances in Water Resources. 51: 317-325.

[19]. Krausman, P.R. Naugle, D.E. Frisina, M.R. Northrup, R. Bleich, V.C. Block, W.M. Wallace, M.C. Wright, J.D. (2009). Livestock Grazing, Wildlife Habitats, and Rangeland Values. Society for Range Management.

[20]. Mainka, S. Trivedi, M. (2002). Links between Biodiversity Conservation, Livelihoods and Food Security: The sustainable use of wild species for meat. IUCN Occasional Papers of the Species Survival Commission No.24.

[21]. Mascia, M. B. (2014). Protected Area Downgrading, Downsizing, and Degazettement (PADDD) in Africa, Asia, and Latin America and the Caribbean, 19002010. Biological Conservation. 169: 355-361.

[22]. Mascia, M. B. Sharon, P (2011). Protected Area Downgrading, Downsizing, and Degazettement (PADDD) and Its Conservation Implications. Conservation Letters. 4 (1): 9-20.doi:10.1111/j.1755-263x.2010.00147.x

[23]. Melillo M.J. (2016). Protected areas' role in climate-change mitigation. Ambio. 45 (2): $133-145$.

[24]. Chape, S. et al. (2005). Measuring the extent and effectiveness of protected areas as an indicator for meeting global biodiversity targets. Phil. Trans. R. Soc. B. 360 (1454): 443-455.

[25]. Muboko, N. Chigumira, T. Mashapa, C. Gandiwa, E. Chibememe, G, Muposhi, V.K. (2014). Impacts of Wood Poaching on Vegetation Structure and Composition in Mukuvisi Woodland, Zimbabwe. Journal of Environmental Protection 5, 156-163.

[26]. Murray, M.G. Williamson, D. (2002). Current issues in biodiversity conservation. Wildlife management working paper Number 4. Food and Agriculture Organisation of the United Nations, Rome.

[27]. Ntuli, H., A. Sundström, M. Sjöstedt, E. Muchapondwa, S. C. Jagers, and A. Linell. (2021). Understanding the drivers of subsistence poaching in the Great Limpopo Transfrontier Conservation Area: What matters for community wildlife conservation? Ecology and Society 26(1):18. https://doi.org/10.5751/ES-12201-260118.

[28]. Nyamadzawo, G. Gwenzi, W. Kanda, A. Kundlande, A. Masona, C. (2013). Understanding the causes, socio-economic and environmental impacts, and management of veld fires in tropical Zimbabwe. Fire Science Reviews 2.2.

[29]. Obour, R. Asare, R. Ankomah, P. Larson, T. (2016). Poaching and its Potential to Impact Wildlife Tourism: An Assessment of Poaching Trends in the Mole National Park in Ghana. Athens Journal of Tourism-3,169-192. 
[30]. Odadi, W. O.; Karachi, M. K.; Abdulrazak, S. A.; Young, T.P. 2011. African wild ungulates compete with or facilitate cattle depending on the season. Science. 333: 17531755.

[31]. Phillips, D. (2017). Environmentalists in Brazil blame the government for Amazon land violence. The Guardian. https://www.theguardian.com/world/2017/jul/09/.

[32]. Rus, A.I. McArthur, C. Mella, V.S.A. Crowther, M.S. (2006). Habitat fragmentation affects the movement and space use of a specialist folivore, the koala. Animal Conservation.

[33]. Spies, T. A.; Hemstrom, M.A.; Youngblood, A.; Hummel, S. (2006). Conserving OldGrowth Forest Diversity in Disturbance-Prone Landscapes. Conservation Biology. 20: 351-362.

[34]. Tafangenyasha, C. Kavhu, B. Vingi, K. (2016). Decline and Die-Back of Woody Plants in a Physiognomic and Floristically Complex Sebungwe Region and the Factors Modifying Mosaic Patch Landscapes at Sengwa Wildlife Area, Zimbabwe. Journal of Ecosystem Ecograph 6: 194.

[35]. Caro, T. Charles, G.K. Clink, D.J. Riggio, J. Weill, A. Whitesell, C. (2014). Terrestrial Protected Areas: Threats and Solutions. USDA Forest Services RMRS-P-71.

[36]. Tjørve, E. (2010). How to resolve the SLOSS debate: lessons from species-diversity models. Journal of Theoretical Biology, 264, 604-612.

[37]. van Oort, H. McLellan, B.N. Serrouya, R. (2011). Fragmentation, dispersal and metapopulation function in remnant populations of endangered mountain caribou. Animal. Conservation. 14, 215-224.

[38]. Voeten, M. M.; Prins, H. H. (1999). Resource partitioning between sympatric wild and domestic herbivores in the Tarangire region of Tanzania. Oecologia. 120: 287-294.

[39]. Wallace, G.N. Barborak, J.M, McFarland, C. (2003). Land Use Planning and Regulation In and Around Protected Areas: A Study of Best Practices and Capacity Building Needs in Mexico and Central America. Durban, South Africa.

[40]. Wilkie, D. S.; Bennett, E. L.; Peres, C. A.; Cunningham, A. A. (2011). The empty forest revisited. Annals of the New York Academy of Sciences. 1223: 120-128.

[41]. World Wildlife Fund (2017) Conservation units under risk. docs.dpaq.de/ 12297-wwfstudie_brasilien. 